\title{
High sulfate concentration enhances iron mobilization from organic soil to water
}

\author{
Caroline Björnerås $(\mathbb{D} \cdot$ Martin Škerlep • Dimitrios Floudas • Per Persson • \\ Emma S. Kritzberg
}

Received: 23 January 2019/Accepted: 9 July 2019/Published online: 13 July 2019

(C) The Author(s) 2019

\begin{abstract}
Widespread increases in iron (Fe) concentrations are contributing to ongoing browning of northern freshwaters, but the driver/s behind the trends are not known. Fe mobilization in soils is known to be controlled by redox conditions, $\mathrm{pH}$, and DOC availability for complexation. Moreover, high sulfate concentrations have been suggested to constrain $\mathrm{Fe}$ in transition from soil to water, and declining sulfate deposition to have the opposite effect. We studied the effect of these Fe mobilization barriers in a microcosm experiment, applying high (peak $\mathrm{S}$ deposition) and low (present day) sulfate treatments and oxic versus anoxic conditions to boreal (O horizon) soil slurries. We hypothesized that anoxic conditions would favor $\mathrm{Fe}$
\end{abstract}

Responsible Editor: Sharon A. Billings.

Electronic supplementary material The online version of this article (https://doi.org/10.1007/s10533-019-00581-6) contains supplementary material, which is available to authorized users.

C. Björnerås $(\varangle) \cdot$ M. Škerlep · E. S. Kritzberg Department of Biology, Aquatic Ecology, Lund University, Sölvegatan 37, 22362 Lund, Sweden e-mail: caroline.bjorneras@biol.lu.se

\section{Floudas · P. Persson}

Department of Biology, Microbial Ecology Group, Lund University, Sölvegatan 37, 22362 Lund, Sweden

\section{P. Persson}

Centre for Environmental and Climate Research (CEC), Lund University, Sölvegatan 37, 22362 Lund, Sweden release. On the contrary we expected high sulfate concentrations to suppress Fe mobility, through FeS formation or by lowering $\mathrm{pH}$ and thereby $\mathrm{DOC}$ concentrations. Anoxia had positive effects on both $\mathrm{Fe}$ and DOC concentrations in solution. Contrasting with our hypothesis, Fe concentrations were enhanced at high sulfate concentrations, i.e. increasing acidity in high sulfate treatments appeared to promote $\mathrm{Fe}$ mobilization. Establishment of the basidiomycete fungus Jaapia ochroleuca in the oxic treatments 44 days into the experiment had a major impact on $\mathrm{Fe}$ mobilization by increasing total $\mathrm{Fe}$ concentrations in solution. Thus, anoxia and acidity, along with fungi mediated mobilization, were important in controlling $\mathrm{Fe}$ release from soil to the aqueous phase. While $\mathrm{Fe}$ is often assumed to precipitate as $\mathrm{Fe}$ (oxy)hydroxides in the transition from anoxic to oxic water in the riparian zone, Fe from anoxic treatments remained in solution after introduction of oxygen. Our results do not support reduced atmospheric $\mathrm{S}$ deposition as a driver behind increasing $\mathrm{Fe}$ concentrations in boreal freshwaters, but confirm the importance of reducing conditions - which may be enhanced by higher soil temperature and moisture-for mobilization of $\mathrm{Fe}$ across the terrestrial-aquatic interphase.

Keywords Iron biogeochemistry - Brownification Boreal soil · Dissolved organic carbon · Jaapia ochroleuca $\cdot$ Reduced atmospheric $\mathrm{S}$ deposition 


\section{Introduction}

Iron $(\mathrm{Fe})$ concentrations in boreal freshwaters in Northern Europe are on the rise, and the increase is happening at a high rate. Björnerås et al. (2017) reported significantly positive trends for $\mathrm{Fe}$ in $39 \%$ out of 213 North European waterbodies analyzed, and that the median increase was $61 \%$ during the period 1990-2013. These striking trends in Fe concentrations are contributing to the ongoing browning of freshwaters (Kritzberg and Ekstrom 2012; Weyhenmeyer et al. 2014). Fe is also known to influence the mobilization and bioavailability of phosphorus (Bakker et al. 2016), and has been suggested to exert a major control on carbon (C) sequestration by affecting flocculation, sedimentation, and preservation of organic $\mathrm{C}$ in sediments (von Wachenfeldt et al. 2008; Lalonde et al. 2012). Thus, given the important role of $\mathrm{Fe}$ in freshwater systems, it is imperative to understand the underlying driver/s of the rising $\mathrm{Fe}$ concentrations.

The main sources of $\mathrm{Fe}$ to aquatic systems are the surrounding catchment soils (Nurnberg and Dillon 1993). Although $\mathrm{Fe}$ is prevalent in the earth crust, the low solubility of $\mathrm{Fe}(\mathrm{III})$, which prevails under oxic conditions and neutral $\mathrm{pH}$, restricts mobility (Stumm and Morgan 1996). Weathering of mineral components of the soil is the first step of Fe mobilization (Giesler et al. 2000). The chemical weathering is enhanced by acidifying compounds of various origins, including organic acids from vegetation and microbes (Drever 1994; Chen et al. 2000; Landeweert et al. 2001). Since positive trends in Fe concentrations were more frequently found in catchments with coniferous forest, land-use changes and expanding forestry may contribute to enhanced $\mathrm{Fe}$ export to freshwaters (Björnerås et al. 2017). Coniferous forests have been shown to enhance weathering rates and mineral fluxes to boreal rivers (Humborg et al. 2004). In podzols, which are the typical soils of coniferous boreal forests, $\mathrm{Fe}$ and organic acids are enriched in the surface (O/A) horizons (Giesler et al. 2000). Metal-organic acid complexes are eluviated from the acidic surface horizons and precipitated in response to the higher $\mathrm{pH}$ and decreased solubility in the subsoil (B horizon) (Bergkvist 1987; Lundstrom et al. 2000). From such soil horizons, Fe can be transported with discharging groundwater entering boreal headwaters (Ledesma et al. 2013; Lidman et al. 2017). The mobilization of $\mathrm{Fe}$ from soils largely requires either association to organic matter (OM) (Jansen et al. 2004), reducing conditions induced by oxygen deficiency (Grybos et al. 2009), or low pH (Kuesel et al. 2001). Reducing conditions promoting microbial $\mathrm{Fe}(\mathrm{III})$ reduction (Lovley 1991), and hence the release of the more mobile Fe(II) from hydrologically connected soils, has been suggested to exert a major control on $\mathrm{Fe}$ concentrations in boreal freshwaters (Sarkkola et al. 2013; Ekstrom et al. 2016; Björnerås et al. 2017). Also, reducing conditions induced by high temperatures and soil moisture stimulate the formation of organic acids that co-transport Fe from soils to adjacent streams (Bergkvist 1987). Hence, $\mathrm{pH}$ and redox conditions, as well as concentration and properties of OM control Fe mobilization in soils. Studies of Fe mobilization from soils to water have traditionally focused on bacterial or abiotic processes, but more recent studies point also to the potential importance of fungi (Clarholm and Skyllberg 2013). The transition from soil to stream, which often includes sharp gradients in these particular factors (Lidman et al. 2017), may represent a second "mobilization barrier" of Fe.

Redox mobilization of Fe may be modulated by the presence of other electron acceptors. For instance, the availability of nitrate $\left(\mathrm{NO}_{3}{ }^{-}\right)$as a competing electron acceptor in soils has been suggested to affect Fe mobilization. Musolff et al. (2017) linked increasing Fe concentrations in mountain streams in Germany to declining atmospheric nitrogen deposition, arguing that the diminishing importance of $\mathrm{NO}_{3}{ }^{-}$as a competing electron acceptor has enhanced $\mathrm{Fe}$ reduction and mobilization.

Another potentially competing electron acceptor in soils is sulfate $\left(\mathrm{SO}_{4}{ }^{2-}\right)$, and the sharp reduction in atmospheric sulfur (S) deposition since the mid 1980s has been suggested to potentially shift anaerobic respiration from $\mathrm{SO}_{4}{ }^{2-}$ to $\mathrm{Fe}$ reduction (Knorr 2013), and thereby to enhance $\mathrm{Fe}$ mobilization. The high availability of $\mathrm{S}$ during phases of high $\mathrm{S}$ deposition may potentially also have suppressed $\mathrm{Fe}$ mobility in soils by formation and precipitation of stable $\mathrm{Fe}$ sulfides (FeS) (Bottrell et al. 2007; Knorr et al. 2009; Knorr 2013). Moreover, the low $\mathrm{pH}$ associated with high $\mathrm{S}$ deposition potentially increased the solubility of Fe minerals, yet suppressed the solubility of high molecular weight DOC (Ekstrom et al. 2011) and thus the solubility of Fe-DOC associations. Hence, assessing the effect of changing $\mathrm{S}$ deposition on Fe mobility 
in soils is not trivial given the potential influence of mobilization mechanisms acting in opposite directions. For instance, the indirect effect of $\mathrm{pH}$ via DOC may be more important for Fe solubility than the direct effect of $\mathrm{pH}$. Along with a reduction in $\mathrm{S}$ deposition a recovery from acidification has followed in many catchments and $\mathrm{SO}_{4}{ }^{2-}$ concentrations in surface waters have generally delined (Schopp et al. 2003; Garmo et al. 2014). A correlation between falling $\mathrm{SO}_{4}{ }^{2-}$ concentrations and rising DOC concentrations across lakes in Northern Europe and North America, suggests that a recovery from acidification may be one underlying driver of frequent trends of increasing DOC (Monteith et al. 2007). A similar relationship was found for increasing $\mathrm{Fe}$ concentrations and declining $\mathrm{SO}_{4}{ }^{2-}$ concentrations in freshwaters (Björnerås et al. 2017), but the underlying mechanism behind such a relationship is poorly understood.

The aim of this study was to experimentally examine the effect of $\mathrm{SO}_{4}{ }^{2-}$ and oxygen on mobilization of Fe from an organic soil. We hypothesized that anoxic conditions would favor the release of $\mathrm{Fe}$ by reductive dissolution, but that high availability of $\mathrm{SO}_{4}{ }^{2-}$ would hamper the release of $\mathrm{Fe}$, by formation of $\mathrm{FeS}$, competition by $\mathrm{SO}_{4}{ }^{2-}$ as an electron acceptor, or by high acidity reducing the DOC available for $\mathrm{Fe}$ complexation. These hypotheses were tested in a microcosm experiment with crossed treatments of high (peak S deposition) and low (present day) $\mathrm{SO}_{4}{ }^{2-}$ treatments and oxic versus anoxic conditions. Additionally, we tested if $\mathrm{Fe}$ mobilized under reducing conditions would be stable against precipitation under oxygenated conditions, relating to the transition zone between hydrologically connected soils and surface waters.

In this study, unexpectedly, growth of the wood decaying fungus Jaapia ochroleuca was found in the oxic treatments 7 weeks into the experiment. The establishment of this fungus was paralleled by a marked change in soil water chemistry. We exploited this unintended event as it likely lowered oxygen concentrations and introduced organic and carbonic acids. By comparing the chemistry before and after the fungus was established we could assess the effect on Fe mobilization.

\section{Methods}

Soil sampling

Soil was sampled at the Asa Experimental Forest and Research Station in southern Sweden $\left(57^{\circ} 08^{\prime} \mathrm{N}\right.$, $14^{\circ} 45^{\prime} \mathrm{E}$, alt. $190-200$ m.a.s.1.). The site is dominated by Norway spruce (Picea abies) with the present stand planted in 1967. Annual mean precipitation in the area is $688 \mathrm{~mm}$, yearly mean temperature is $5.5^{\circ} \mathrm{C}$, and the average length of the growing season is 190 days (Kleja et al. 2008). The bedrock consists of granites and porphyries covered with sandy till (sand 55\%, silt $42 \%$ and clay 3\%) (Berggren et al. 2004). Soil at the sampling site is a podzol with an O-horizon of $3-10 \mathrm{~cm}$ depth with a total carbon pool of $4.3 \mathrm{~kg} \mathrm{~m}^{-2}$ (Froberg et al. 2005).

Soil was sampled from a location where plots were subjected to an irrigation experiment to study the effect of acid deposition on DOC concentration and chemical character using the same $\mathrm{SO}_{4}{ }^{2-}$ regimes as in the present work (Ekstrom et al. 2011). Soil from the O horizon was collected, excluding surface litter, and directly sieved through a coarse sieve. The soil was left to air-dry for 3 days before it was sieved through a 2-mm sieve and left to dry for another 2 days. Before dividing the soil between microcosms it was homogenized. The soil had a $\mathrm{pH}_{\mathrm{H}_{2} \mathrm{O}}$ of 3.45 (soil to water ratio 1:4 wt:wt), consisted mainly of $\mathrm{OM}(78 \%)$, and contained $41.4,106,0.85$, and $31.3 \mu \mathrm{mol} \mathrm{g}^{-1}$ of Fe, $\mathrm{Al}, \mathrm{Mn}$, and $\mathrm{S}$ respectively.

\section{Microcosm experiment}

Pyrex bottles (1.2 L) were used for the microcosms, to which $110 \mathrm{~g}$ dry soil and $1.1 \mathrm{~L}$ of artificial rainwater were added. Soil slurries were exposed to two levels of $\mathrm{SO}_{4}{ }^{2-}$ concentration and oxic versus anoxic conditions in a 2 by 2 design to test the effect on $\mathrm{Fe}$ mobilization. Each treatment was run in four replicates, resulting in 16 microcosms in total. The two $\mathrm{SO}_{4}{ }^{2-}$ treatments were chosen to represent precipitation with current levels of $\mathrm{SO}_{4}{ }^{2-}$ (LS) and levels representative for peak $\mathrm{S}$ deposition in the 1980s (HS). The artificial rainwater was prepared according to Ekstrom et al. (2011). The two different $\mathrm{SO}_{4}{ }^{2-}$ treatments contained 0.012 and $0.36 \mathrm{mM} \mathrm{H}_{2} \mathrm{SO}_{4}$, respectively. $\mathrm{pH}$ was 6.74 in the $\mathrm{LS}$ and 3.35 in the HS 
treatment water, which is within the range of $\mathrm{pH}$ measured in throughfall in southern Sweden spruce forest during peak acidification (Bergkvist 1986; Sanden et al. 1987; Påhlsson and Bergkvist 1995). Each $\mathrm{SO}_{4}{ }^{2-}$ treatment was run under oxic $(\mathrm{O})$ and anoxic (A) conditions.

Anoxic replicates were sealed with rubber lids, which had 6-mm tubes sealed with valves inserted through them, so that sampling was possible without introduction of oxygen. One of the tubes reached halfway into the soil solution to enable sampling while the other end of the tube had its opening in the air pocket at the top of the bottle. Oxic replicates were left open, to enable steady-state oxygen conditions in the soil solutions. All the material and sampling equipment were acid washed before the start of the experiment, with reusable equipment also being acid washed before every sampling. The microcosms were mixed and placed on a rotation table $(45 \mathrm{rpm})$, where they were incubated in darkness in a temperaturecontrolled room $\left(20^{\circ} \mathrm{C}\right)$.

The experiment ran for 134 days, during which time sampling was conducted on 15 occasions. A 20-mL syringe was used for sampling. When sampling anoxic samples the syringe was attached to the valves, while a tube was attached to the syringe for the oxic samples. From the anoxic treatments, a small volume was discarded at each sampling to get rid of the water in the sampling tube. Two 20-mL samples were taken from each replicate; the first was immediately used for measuring oxygen $\left(\mathrm{O}_{2}\right)$, redox potential $(\mathrm{Eh})$ and $\mathrm{pH}$. The second sample was filtered $(\mathrm{GF} / \mathrm{F}$, Whatman, pore size: $0.7 \mu \mathrm{m}$ ), split into two 20 -mL plastic vials and stored frozen for later analyses of total $\mathrm{Fe}, \mathrm{Fe}(\mathrm{II}), \mathrm{Mn}$, $\mathrm{Al}, \mathrm{SO}_{4}{ }^{2-}, \mathrm{NO}_{3}{ }^{-}, \mathrm{PO}_{4}{ }^{3-}$ and DOC concentrations. Thus, the phase that was analyzed to assess mobilization from soil may also have contained suspended particles $<0.7 \mu \mathrm{m}$. After sampling the volume was replaced by adding the rainwater according to the assigned treatment. Losses by evaporation were replaced so that the volume was kept constant throughout the experiment. For anoxic samples artificial rainwater was nitrogen bubbled for $15 \mathrm{~min}$ before addition.

Fungal identification

Part of the fruitbody of the fungal species that grew on the surface of the submerged soil was collected and air-dried for a week. A small section of the dried sample was placed on a glass slide, and the tissue was stained with a $1.5 \%$ Phloxine B solution, followed by addition of a small amount of $2 \% \mathrm{KOH}$ solution. A second section was stained using a small amount of Melzer solution. The sections were examined using an inverted microscope (Nikon DIAPHOT 300), for the presence of basidia, clamp connections, spores, and cystidial elements. About thirty basidiospores were measured. Photographs of the microscopic characteristic of the fungus were acquired using a DMK 33UX174 digital camera.

\section{Re-oxidation experiment}

To test to what extent filterable $\mathrm{Fe}$ from anoxic treatments would remain in solution after oxygenation a re-oxidation experiment was performed. On day 83, $40 \mathrm{ml}$ of soil solution was removed from the anoxic microcosms and filtered through GF/F filter. A subsample of $10 \mathrm{~mL}$ was immediately fixed for $\mathrm{Fe}$ analysis and the remaining sample was transferred into 50-mL Falcon tubes. These were then left open on a rotation table $(45 \mathrm{rpm})$ for $48 \mathrm{~h}$ to allow oxygenation. After this, samples were centrifuged (3000 rcf) for $8 \mathrm{~h}$ at $4{ }^{\circ} \mathrm{C}$ to separate particles from the suspension. The supernatant of each sample was analyzed for $\mathrm{Fe}$ and compared to concentrations before oxidation.

Analytical methods

Total $\mathrm{Fe}, \mathrm{Mn}$, and $\mathrm{Al}$ concentrations were analyzed with ICP-OES (Perkin Elmer Optima 8300). For metal analyses, soil solution samples were acidified (1\% $\mathrm{HNO}_{3}$ ) $24 \mathrm{~h}$ before analysis, while a soil sample was extracted in $7 \mathrm{M} \mathrm{HNO}_{3}$ and measured according to SS 28311 (2017). A subset of samples representing the beginning of the experiment (day 3 ), before the fungus was detected (day 16), and after the fungus had established in the oxic microcosms (day 73) were analyzed by the Ferrozine method for Fe(II) (Viollier et al. 2000). Absorbance of the Ferrozine solutions were recorded at $562 \mathrm{~nm}$ on a Beckman DU 800 Coulter spectrophotometer. $\mathrm{SO}_{4}{ }^{2-}, \mathrm{NO}_{3}{ }^{-}$, and $\mathrm{PO}_{4}{ }^{3-}$ concentrations were analyzed with Ion chromatography (816 Advanced Compact IC, Metrohm).

A Unisense Microsensor Multimeter (Version 2.01) attached with several electrodes was used for measurements of $\mathrm{O}_{2}\left(\mathrm{OX}-100\right.$; Unisense), $\mathrm{H}_{2} \mathrm{~S}\left(\mathrm{H}_{2} \mathrm{~S}-100\right.$; 
Unisense) and redox potential (RD-100; Unisense). Since the $\mathrm{H}_{2} \mathrm{~S}$ electrode did not produce a stable and reliable signal, results for this electrode are not presented. For $\mathrm{pH}$ measurements a $913 \mathrm{pH}$ Meter (Metrohm) was used.

DOC concentrations were analyzed on a Shimadzu TOC V-CPN analyzer, using the non-purgeable organic matter method (NPOC). Soil OM content was determined by loss of ignition (LOI) at $400{ }^{\circ} \mathrm{C}$ during $8 \mathrm{~h}$.

\section{Statistics}

The treatment effects on all continuously measured variables $\left(\mathrm{O}_{2}, \mathrm{pH}\right.$, redox, total $\mathrm{Fe}, \mathrm{Al}, \mathrm{Mn}, \mathrm{SO}_{4}{ }^{2-}, \mathrm{DOC}$, $\mathrm{NO}_{3}{ }^{-}$and $\mathrm{PO}_{4}{ }^{3-}$ ) were investigated using two-way repeated measures ANOVAs. To correct for violations of sphericity, Greenhouse-Geisser corrections were applied. The data from the period when no fungi were detected (NF, day 1-44) and the period with fungi established in the oxic treatments (WF, day 44-134) were analyzed separately. During NF, the influence of $\mathrm{SO}_{4}{ }^{2-}$ concentration and oxic versus anoxic conditions on the response variables could be assessed. By comparing the influence on the response variables between NF and WF the effect of the fungus could be evaluated. Differences in Fe concentration between the $\mathrm{O}$ and $\mathrm{A}$ treatments at the end of the experiment (day 134), as well as differences in Fe(II) concentrations between treatments for day 3,16 , and 73, were analyzed using a Two-Way ANOVA. Differences in Fe concentration between anoxic and re-oxidized samples were tested by paired samples $t$ test. All statistical analyses were performed with IBM SPSS Statistics v.25 and plots were created with GraphPad Prism v.7.

\section{Results}

\section{Experimental conditions}

The targeted experimental conditions were achieved regarding $\mathrm{O}_{2}$ and $\mathrm{SO}_{4}{ }^{2-}$ concentrations (Fig. 1). A sharp decline in dissolved $\mathrm{O}_{2}$ was observed in all treatments during the first days of the experiment, probably as a result of strongly enhanced microbial activity (Fig. 1a). Well-oxygenated conditions were established after 3 days in the assigned oxic treatments, while low and stable $\mathrm{O}_{2}$ conditions prevailed in the anoxic treatments throughout the experiment (Fig. 1a). Accordingly, $\mathrm{O}_{2}$ concentrations were significantly higher in the oxic than in the anoxic treatments $\left(\mathrm{F}=1.50 \times 10^{3}, \mathrm{p}<0.001\right)$, and did not differ between $S$ treatments $(F=0.78, p=0.39)$. The oxic treatments were not saturated with oxygen, but dissolved oxygen was on average $73 \%$ compared to $4 \%$ in the anoxic treatments. Redox potential measurements reflected differences in $\mathrm{O}_{2}$ concentration with lower redox potential in the sealed $(357 \pm 85.1 \mathrm{mV})$ than in the open microcosms $(481 \pm 64.1 \mathrm{mV})(\mathrm{F}=400, \mathrm{p}<0.001)$.

The HS treatments had significantly higher $\mathrm{SO}_{4}{ }^{2-}$ concentration than the LS treatments throughout the experiment $(\mathrm{F}=365, \mathrm{p}<0.001)$, while there was no difference in $\mathrm{SO}_{4}{ }^{2-}$ between oxic and anoxic treatments $(\mathrm{F}=0.08, \mathrm{p}=0.78)$.

On day 44, growth of fungal mycelium on the submerged litter was detected in the oxic treatments. The growth continued until the mycelium formed a thick cover on the litter material. Examination of this tissue under the microscope revealed that the hyphae had clamp connections and therefore, belonged to a basidiomycete fungus (Fig. S1). Further examination of the tissue revealed that it represented a fruitbody of Jaapia ochroleuca (Bres.) Nannf. \& J. Erikss. based on the characteristics of the basidiospores (fusiform to narrowly ellipsoid, slightly thick-walled, $11.2-15.4 \times 4.1-5.7 \mu \mathrm{m}$, however, not obviously dextrinoid) and the cystidia (tubular, at least $100 \mu \mathrm{m}$ long, with thickening cell wall towards the base). The experimental period before and after day 44 , when the fungus was noticed are termed NF and WF (no fungus and with fungus), respectively.

Effect of presence/absence of oxygen and S availability on Fe mobilization (NF)

The $\mathrm{pH}$ at the start of the experiment was on average $3.45( \pm 0.04)$ and $3.61( \pm 0.01)$, in the HS and LS treatments respectively, and $3.64( \pm 0.09)$ and 3.81 $( \pm 0.09)$ at day 44, (Fig. 2a). Thus $\mathrm{pH}$ was significantly lower in HS than LS $(F=205, p<0.001)$. Moreover, $\mathrm{pH}$ was somewhat lower in the anoxic than the oxic treatments $(\mathrm{F}=7.21, \mathrm{p}<0.05)$. During this part of the experiment $\mathrm{pH}$ increased in all treatments $(\mathrm{F}=33.2, \mathrm{p}<0.001)$. The lack of interaction between time and the treatment factors indicate that the increase in $\mathrm{pH}$ did not differ across treatments 
Fig. 1 Mean dissolved oxygen $\left[\mathrm{O}_{2}\right](\mathbf{a})$ and sulfate $\left[\mathrm{SO}_{4}^{2-}\right](\mathbf{b})$ concentration in the four treatments over time. $H S$ high sulfuric acid treatments, $L S$ low sulfuric acid treatments, $O$ oxic treatments, and $A$ anoxic treatments. Error bars \pm 1 SD. NF (white background) and WF (grey background) highlight the period before and after the influence of fungal growth in the $\mathrm{O}$ treatments
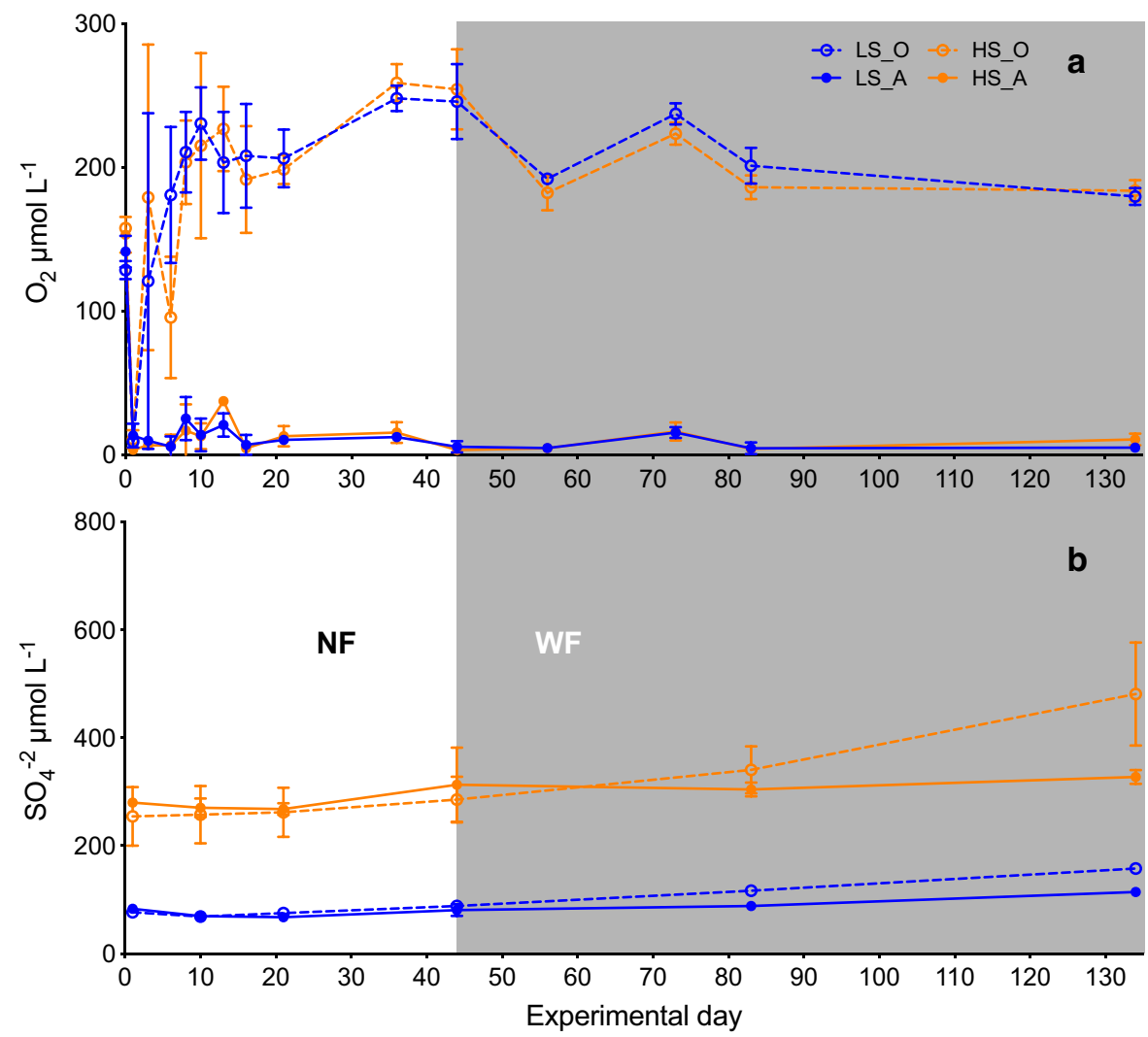

$\left(\mathrm{F}_{\text {time } \times \mathrm{O}_{2}}=2.13, \quad \mathrm{p}_{\text {time } \times \mathrm{O}_{2}}=0.09\right.$, and $\mathrm{F}_{\text {time } \times \mathrm{SO}_{4}}=$ 2.64, $\left.\mathrm{p}_{\text {time } \times \mathrm{SO}_{4}}=0.05\right)$.

Both total $\mathrm{Fe}$ and DOC concentrations increased in all treatments over time (Fig. 2b, c; $\mathrm{F}_{\mathrm{Fe}}=184$, $\mathrm{p}_{\mathrm{Fe}}<0.001$, and $\mathrm{F}_{\mathrm{DOC}}=181, \mathrm{p}_{\mathrm{DOC}}<0.001$ respectively). Initial total Fe concentration was on average $3.8( \pm 0.5) \mu \mathrm{mol} \mathrm{L} \mathrm{L}^{-1}$ and on day 44 it was $8.3( \pm 3.2)$ and $15.7( \pm 4.0) \mu \mathrm{mol} \mathrm{L} \mathrm{L}^{-1}$ in the oxic and anoxic treatments, respectively. Thus, as hypothesized, lack of oxygen had a significantly positive effect on $\mathrm{Fe}$ $(\mathrm{F}=70.4, \mathrm{p}<0.001)$, although the increase in total $\mathrm{Fe}$ concentration was small. However, total Fe concentrations in solution were not lower in HS than in LS as hypothesized, but instead higher $(\mathrm{F}=14.5$, $\mathrm{p}<0.01)$. The rate of increase in total $\mathrm{Fe}$ was significantly different between both $\mathrm{O}_{2}$ and $\mathrm{SO}_{4}$ treatments $\quad\left(\mathrm{F}_{\text {time } \times \mathrm{O}_{2}}=29.9, \mathrm{p}_{\text {time } \times \mathrm{O}_{2}}<0.001\right.$, and $\left.\mathrm{F}_{\text {time } \times \mathrm{SO}_{4}}=19.4, \mathrm{p}_{\text {time } \times \mathrm{SO}_{4}}<0.001\right)$. At day $3 \mathrm{Fe}(\mathrm{II})$ concentrations were independent of both $\mathrm{O}_{2}$ and $\mathrm{SO}_{4}$ treatments (Fig. 3) $\quad\left(\mathrm{F}_{\mathrm{O}_{2}}=0.95, \mathrm{p}_{\mathrm{O}_{2}}=0.36\right.$, and $\left.\mathrm{F}_{\mathrm{SO}_{4}}=1.26, \mathrm{p}_{\mathrm{O}_{2}}=0.30\right)$. On day 16 however, $\mathrm{Fe}(\mathrm{II})$ concentrations were positively affected by A and HS conditions $\quad\left(\mathrm{F}_{\mathrm{O}_{2}}=181, \mathrm{p}_{\mathrm{O}_{2}}<0.001\right.$, and $\mathrm{F}_{\mathrm{SO}_{4}}=$ 13.0, $\left.\mathrm{p}_{\mathrm{O}_{2}}<0.01\right)$. The mean dissolved $\mathrm{Fe}$ to $\mathrm{S}$ molar ratio was $7.11 \times 10^{-2}$ for the LS treatments and $2.48 \times 10^{-2}$ for the HS treatments.

The DOC concentration started at 10.4 $( \pm 1.4) \mathrm{mmol} \mathrm{L}^{-1}$ and increased to higher levels in the anoxic treatments $\left(22.2 \pm 0.5 \mathrm{mmol} \mathrm{L}^{-1}\right)$ than in the oxic treatments $\left(8.1 \pm 1.2 \mathrm{mmol} \mathrm{L}^{-1} ; \mathrm{F}=520\right.$, $\mathrm{p}<0.001)$. Moreover, mean DOC concentrations were significantly higher in LS than HS $(F=10.7$, $\mathrm{p}<0.01)$. The lack of interaction between time and $\mathrm{S}$ $\left(\mathrm{F}_{\text {time }} \times \mathrm{SO}_{4}=0.65, \mathrm{p}_{\text {time } \times \mathrm{SO}_{4}}=0.58\right)$ and significant time $\times \mathrm{O}_{2}, \quad\left(\mathrm{~F}_{\text {time } \times \mathrm{O}_{2}}=160, \mathrm{p}_{\text {time } \times \mathrm{O}_{2}}<0.001\right)$ indicate that the response in DOC to the $\mathrm{O} / \mathrm{A}$ treatment was independent of $\mathrm{SO}_{4}{ }^{2-}$ concentration (Fig. 2c).

The Fe:DOC ratio was low in all treatments, although slightly higher in the oxic than in the anoxic treatments $\left(5.5 \times 10^{-4}\right.$ and $4.6 \times 10^{-4}$ respectively).

\section{Mobilization of Fe in presence of fungi (WF)}

During this period (day 44-134), hyphae covered the soil of the microcosms of the $\mathrm{O}$ treatments, and formed 
Fig. 2 Mean $\mathrm{pH}(\mathbf{a}), \mathrm{Fe}$ concentration (b), and DOC concentration (c) in the four treatments over time. $H S$ high sulfuric acid treatments, $L S$ low sulfuric acid treatments, $O$ oxic treatments, and $A$ anoxic treatments. Error bars \pm 1 SD. NF (white background) and WF (grey background) highlight the period before and after the influence of fungal growth in the $\mathrm{O}$ treatments
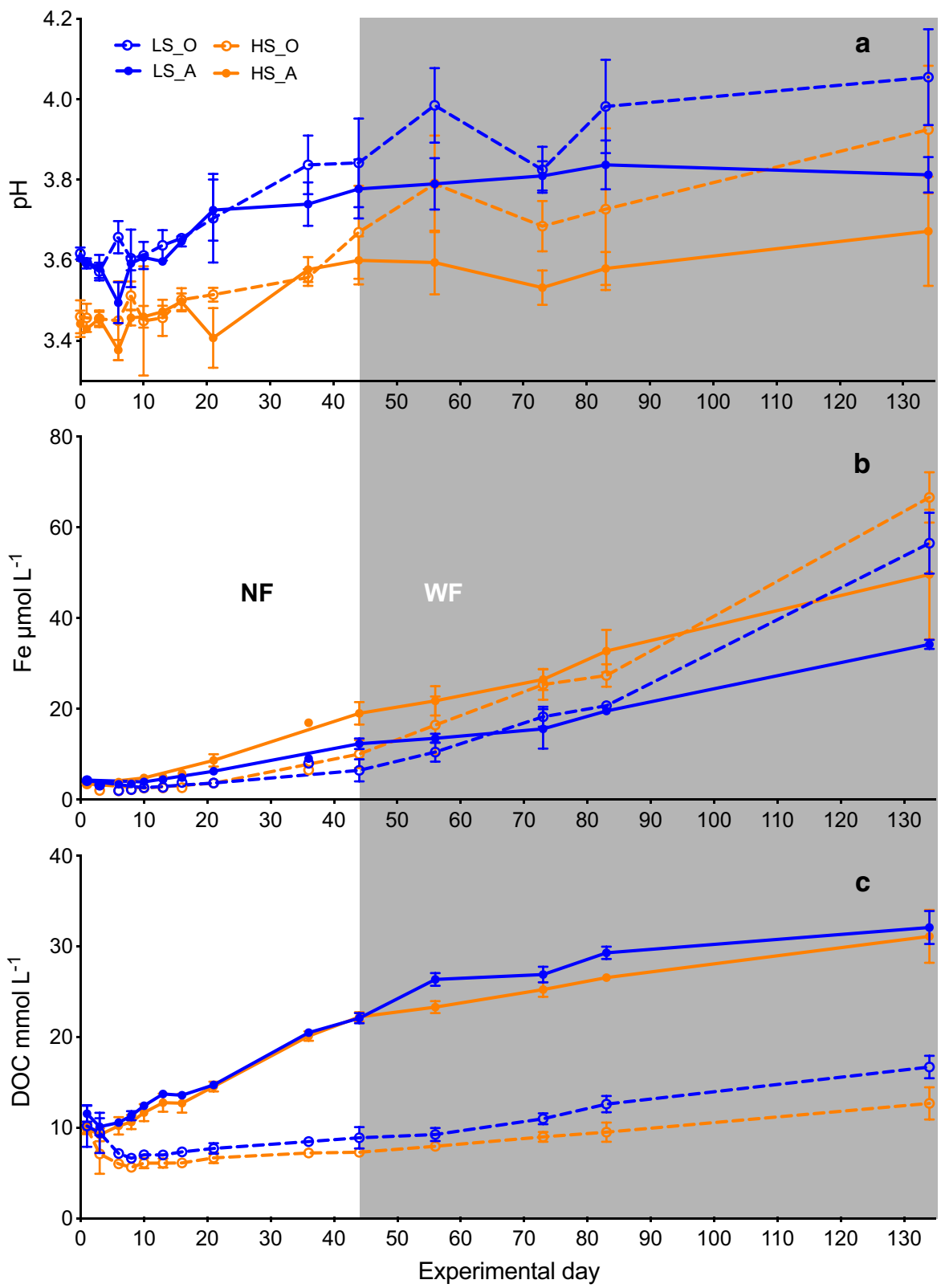

a layer that was approximately $0.5 \mathrm{~cm}$ thick at the end of the experiment. When the experiment was terminated, oxygen concentrations were measured in the fungal layer and in the soil below, revealing low concentrations in the fungal cover, and anoxic conditions in the soil (results not shown). Thus, the high $\mathrm{O}_{2}$ concentrations of the $\mathrm{O}$ treatments measured also after day 44 , represent only the volume above the fungal layer.
During WF, $\mathrm{pH}$ continued to increase in all treatments $(\mathrm{F}=6.33, \mathrm{p}<0.01)$, and was highest in LS_O throughout the experiment (Fig. 2a). Total Fe and DOC concentrations continued to rise too in all treatments $\left(\mathrm{F}_{\mathrm{Fe}}=252, \quad \mathrm{p}_{\mathrm{Fe}}<0.001, \quad \mathrm{~F}_{\mathrm{DOC}}=164\right.$, $\left.\mathrm{p}_{\mathrm{DOC}}<0.001\right)$ with total $\mathrm{Fe}$ concentrations being significantly higher in HS than in LS while the pattern remained the opposite for DOC during WF $\left(\mathrm{F}_{\mathrm{Fe}}\right.$ $\left.=34.7, \mathrm{p}_{\mathrm{Fe}}<0.001, \mathrm{~F}_{\mathrm{DOC}}=31.8, \mathrm{p}_{\mathrm{DOC}}<0.001\right)$. However, while DOC concentrations were higher in 
the A treatments throughout the experiment there was no longer a significant difference in total $\mathrm{Fe}$ between the $\mathrm{O}$ and $\mathrm{A}$ treatments $\left(\mathrm{F}_{\mathrm{DOC}}=1992, \mathrm{p}_{\mathrm{DOC}}<0.001\right.$, $\left.\mathrm{F}_{\mathrm{Fe}}=0.81, \mathrm{p}_{\mathrm{Fe}}=0.39\right)$. Instead, Fe release from the $\mathrm{O}$ treatments with fungi exceeded those in the anoxic microcosms at the end of the experiment $(\mathrm{F}=22.0$, $\mathrm{p}<0.01)$. On day 73 there was an interaction between $\mathrm{O}_{2}$ and $\mathrm{SO}_{4}$ treatments on $\mathrm{Fe}$ (II) (Fig. 3) $\left(\mathrm{F}_{\mathrm{O}_{2} \times \mathrm{SO}_{4}}=14.3, \mathrm{p}_{\mathrm{O}_{2} \times \mathrm{SO}_{4}}<0.01\right)$. Testing the effect of $\mathrm{O}_{2}$ treatments as a single factor, $\mathrm{Fe}$ (II) concentrations were significantly higher in A compared to $\mathrm{O}$ treatments $\left(\mathrm{F}_{\mathrm{O}_{2}}=12.4, \mathrm{p}_{\mathrm{O}_{2}}<0.01\right)$.

Overall, only a small fraction of the Fe pool was mobilized in the soil during the experiment. From the $4.6 \mathrm{mmol} \mathrm{Fe}$ that was available in each microcosm initially, between 0.9 (LS_A) and $1.7 \%$ (HS_O) was detected in solution on day 134.

\section{Other element fluxes}

Both $\mathrm{Al}$ and $\mathrm{Mn}$ concentrations were highest in HS_A throughout the experiment and appeared unaffected by the growth of fungi in the $\mathrm{O}$ treatments (Fig. 4). Mn mobilization was enhanced in the $\mathrm{A}$ and $\mathrm{HS}$ treatments during $\mathrm{NF}\left(\mathrm{F}_{\mathrm{O}_{2}}=9.67, \mathrm{p}_{\mathrm{O}_{2}}<0.01\right.$, and $\mathrm{F}_{\mathrm{SO}_{4}}=156$, $\left.\mathrm{p}_{\mathrm{SO}_{4}}<0.001\right)$, as well as during $\mathrm{WF}\left(\mathrm{F}_{\mathrm{O}_{2}}=9.69\right.$, $\mathrm{p}_{\mathrm{O}_{2}}<0.05$, and $\mathrm{F}_{\mathrm{SO}_{4}}=145, \mathrm{p}_{\mathrm{SO}_{4}}<0.001$ ), although $\mathrm{Mn}$ concentrations in $\mathrm{O}$ exceeded those in A towards the end of the experiment, as indicated by the significant interaction between treatment factors during $\mathrm{WF}\left(\mathrm{F}_{\mathrm{O}_{2} \times \mathrm{SO}_{4}}=7.02, \mathrm{p}_{\mathrm{O}_{2} \times \mathrm{SO}_{4}}<0.05\right)$. For $\mathrm{Al}$, significant interactions between treatment factors during both NF and WF show that treatment effects were not consistent throughout the experiment (NF:
$\mathrm{F}_{\mathrm{O}_{2} \times \mathrm{SO}_{4}}=57.0, \quad \mathrm{p}_{\mathrm{O}_{2} \times \mathrm{SO}_{4}}<0.001, \quad$ WF: $\quad \mathrm{F}_{\mathrm{O}_{2} \times \mathrm{SO}_{4}}=$ 96.1, $\left.\mathrm{p}_{\mathrm{O}_{2} \times \mathrm{SO}_{4}}<0.001\right)$.

$\mathrm{NO}_{3}{ }^{-}$concentrations dropped in the four treatments until day 10 and stayed low during NF (Fig. 5a). Accordingly, there was no significant difference in $\mathrm{NO}_{3}{ }^{-}$between the $\mathrm{O}$ and $\mathrm{S}$ treatments $\left(\mathrm{p}_{\mathrm{O}_{2}}>0.05\right)$. The presence of fungi may have had a negative effect on $\mathrm{NO}_{3}{ }^{-}$concentration, since concentrations were significantly higher in A compared to $\mathrm{O}$, while there was no significant difference between LS and HS $\left(\mathrm{F}_{\mathrm{O}_{2}}=7.74, \mathrm{p}_{\mathrm{O}_{2}}<0.05, \mathrm{~F}_{\mathrm{SO}_{4}}=1.75, \mathrm{p}_{\mathrm{SO}_{4}}=0.21\right)$. In contrast, $\mathrm{PO}_{4}{ }^{3-}$ concentrations increased during WF and there was no significant difference between treatments ( $p>0.05$ ) (Fig. 5b). During NF, higher $\mathrm{PO}_{4}{ }^{3-}$ was detected in LS compared to HS and in A compared to $\mathrm{O} \quad\left(\mathrm{F}_{\mathrm{O}_{2}}=9.45, \quad \mathrm{p}_{\mathrm{O}_{2}}<0.05\right.$, and $\left.\mathrm{F}_{\mathrm{SO}_{4}}=15.0, \mathrm{p}_{\mathrm{SO}_{4}}<0.01\right)$.

Re-oxidation experiment

When water samples from the anoxic treatments at day 83 were allowed to oxidize, no loss of Fe from solution was observed, i.e. total $\mathrm{Fe}$ concentrations in the reoxidized samples were not lower than the anoxic samples $\left(\mathrm{t}=2.30 \times 10^{-2}, \mathrm{p}=0.98\right)$.

\section{Discussion}

Redox-driven Fe mobilization from soil to waterthe role of $\mathrm{O}_{2}$

The desired experimental conditions were achieved early on with $\mathrm{SO}_{4}{ }^{2-}$ and $\mathrm{pH}$ levels corresponding to
Fig. 3 Mean Fe(II) concentration in the four treatments over time. $H S$ high sulfuric acid treatments, $L S$ low sulfuric acid treatments, $O$ oxic treatments, and $A$ anoxic treatments. Error bars \pm 1 SD. NF (white background) and WF (grey background) highlight the period before and after the influence of fungal growth in the $\mathrm{O}$ treatments

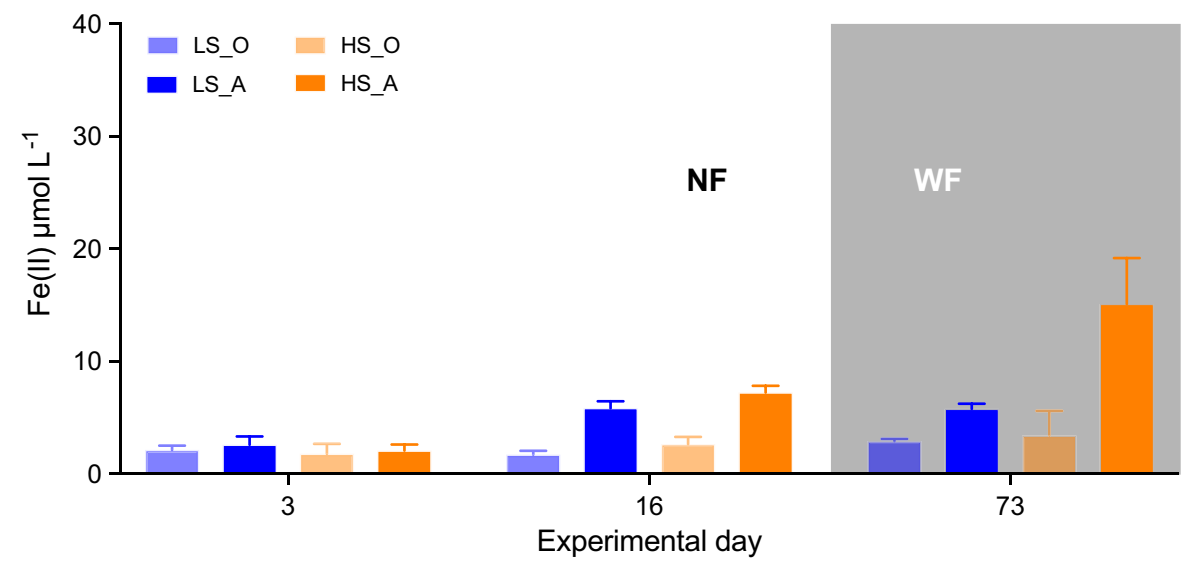


Fig. 4 Mean Mn (a), and $\mathrm{Al}$ concentration $(\mathbf{b})$ in the four treatments over time. $H S$ high sulfuric acid treatments, $L S$ low sulfuric acid treatments, $O$ oxic treatments, and $A$ anoxic treatments. Error bars \pm 1 SD. NF (white background) and WF (grey background) highlight the period before and after the influence of fungal growth in the $\mathrm{O}$ treatments
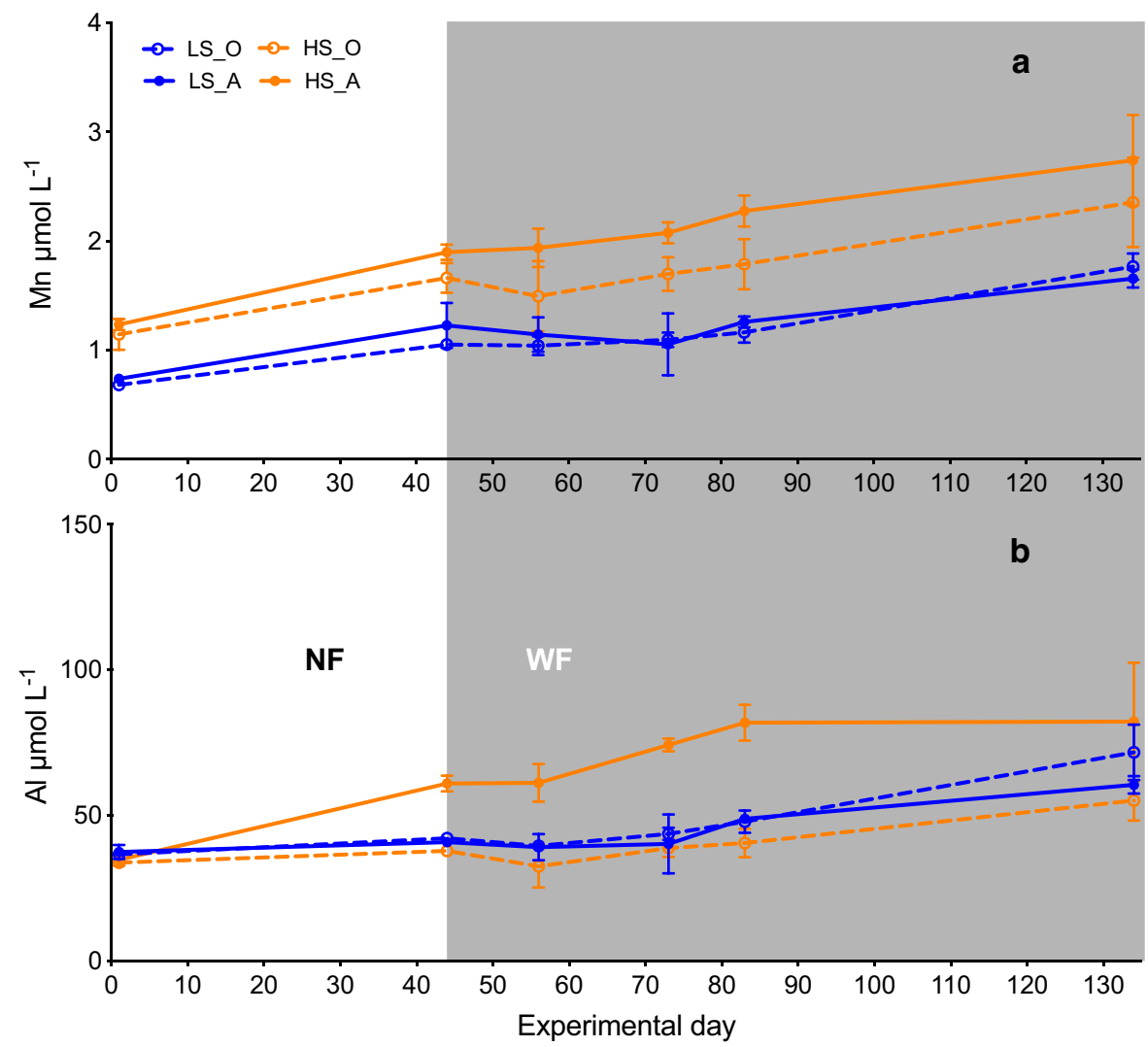

those found in throughfall in the 1980s (HS) and at the present (LS) (Ekstrom et al. 2011). The water in the open microcosms was high in dissolved oxygen, while in the sealed microcosms oxygen was rapidly consumed. As expected, Fe mobilization was favored by anoxic conditions and total $\mathrm{Fe}$ concentrations in solution were roughly twofold higher in anoxic compared to oxic treatments at day 44. Reductive dissolution of $\mathrm{Fe}$ (III) to $\mathrm{Fe}$ (II) was likely contributing to the higher total $\mathrm{Fe}$ concentrations in the anoxic treatments, considering that reducing conditions-i.e. $\mathrm{Eh}<500 \mathrm{mV}$ at $\mathrm{pH} 4$ (Takeno 2005)—prevailed in the anoxic treatments. This is supported by the higher $\mathrm{Fe}(\mathrm{II})$ concentrations in the anoxic treatments. Furthermore, reductive dissolution may have contributed to the more moderate rise in $\mathrm{Fe}$ over time in the oxygenated microcosms as well, given that there may be heterogeneity with suboxic microenvironments and that the average redox potential was fairly low (mean $\mathrm{Eh}=481 \mathrm{mV}$ ). However, increases in total Fe concentrations over time does not necessarily derive solely from $\mathrm{Fe}$ (III) reduction but could also be due to non-reductive extraction of Fe complexed by organic matter. Interestingly, only a minor fraction of the total Fe pool was mobilized $(<2 \%)$, demonstrating that most $\mathrm{Fe}$ was in a form not readily available for dissolution, potentially in mineral grains mixed into the organic layer (Giesler et al. 2000).

DOC concentrations were also significantly higher in the anoxic treatments, potentially due to higher mineralization rates in the oxic treatments, as well as due to $\mathrm{OM}$ solubilization under reducing conditions (Grybos et al. 2009). Sorption of DOC to metal oxides (including (oxy)hydroxides) in soils have been suggested to be an important mechanism contributing to the preservation of soil OC (Kaiser and Guggenberger 2000), as well as the cause of release of DOC upon reductive dissolution of $\mathrm{Fe}$ in boreal soils (Hagedorn et al. 2000; Fiedler and Kalbitz 2003; Pan et al. 2016). DOC sorption capacities of Fe oxides in boreal soils range from molar DOC:Fe ratios below 10 (Moore 1988; Hagedorn et al. 2000) to 39 (Musolff et al. 2017). However, while the increase in Fe in the current experiment was in the $\mu$ molar range, the increase in 
Fig. 5 Mean $\mathrm{NO}_{3}{ }^{-}$(a), and $\mathrm{PO}_{4}{ }^{3-}$ concentration (b) in the four treatments over time. $H S$ high sulfuric acid treatments, $L S$ low sulfuric acid treatments, $O$ oxic treatments, and $A$ anoxic treatments. Error bars \pm 1 SD. NF (white background) and WF (grey background) highlight the period before and after the influence of fungal growth in the $\mathrm{O}$ treatments

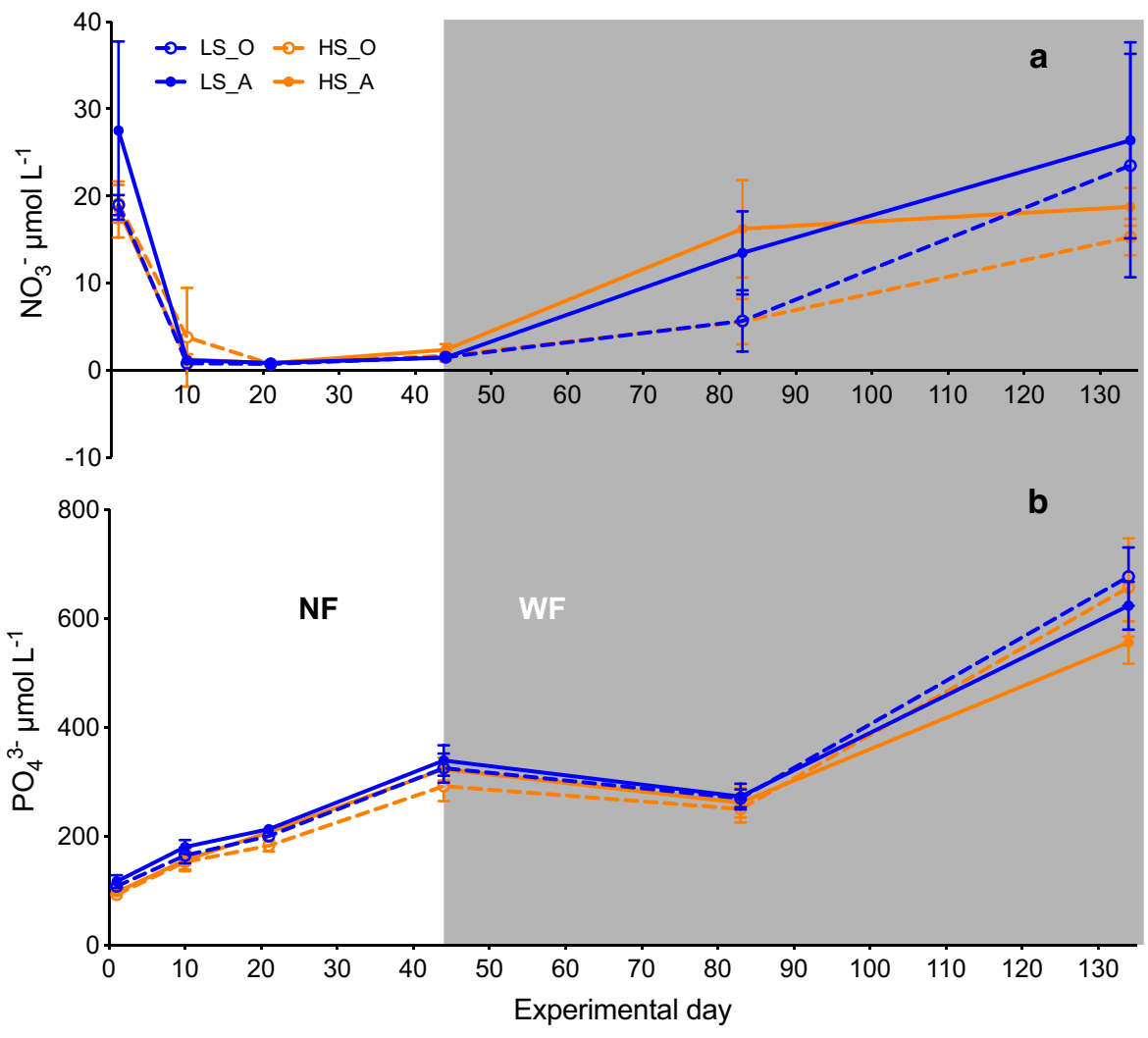

DOC was in the mmolar range. This suggests that the main explanation behind the higher DOC concentration in the anoxic treatments was not the release of adsorbed/co-precipitated organic carbon from reductive dissolution of $\mathrm{Fe}$, even if it is likely that some $\mathrm{OC}$ was released by this process (Skoog and AriasEsquivel 2009; Pan et al. 2016), but rather that the degradation of DOC was impaired by the lack of oxygen (Bastviken et al. 2004). Finally, given the low $\mathrm{Fe}: \mathrm{OC}$ ratios in all microcosms $\left(\sim 5 \times 10^{-4}\right)$, it is not likely that availability of DOC was the main driver behind differences in $\mathrm{Fe}$ concentration between treatments. Fe complexing capacities corresponding to Fe:OC ratios between 0.024 and 0.16 for freshwater DOM (Neubauer et al. 2013a; Xiao et al. 2013) suggest that DOC for Fe complexation was available in excess throughout the experiment.

An increase in $\mathrm{Fe}$ due to release of $\mathrm{Fe}$ (II) in reducing conditions has been previously demonstrated in microcosm experiments (Schuth et al. 2015), and reduction of $\mathrm{Fe}$ (III) occurs at higher Eh when soil $\mathrm{pH}$ is lowered (Atta et al. 1996). This is further supported by the fact that the increase in total Fe began when the
$\mathrm{NO}_{3}{ }^{-}$, a potentially competing electron acceptor, was depleted. The rapid decrease in $\mathrm{NO}_{3}{ }^{-}$and increase in $\mathrm{PO}_{4}{ }^{3-}$, followed by an increase in $\mathrm{Fe}$ and $\mathrm{Mn}$, is in agreement with observations by De-Campos et al. (2012) from short-term flooded terrestrial soils. The concurrent increase in $\mathrm{PO}_{4}{ }^{3-}$ with $\mathrm{Fe}$ may be due to reductive dissolution of $\mathrm{Fe}(\mathrm{III})$ and release of $\mathrm{Fe}$ bound $\mathrm{PO}_{4}{ }^{3-}$ (Ponnamperuma 1972). However, since the increase in $\mathrm{PO}_{4}{ }^{3-}$ far exceeded that of $\mathrm{Fe}$, additional mechanisms such as mineralization of organic matter, or desorption due to lower ionic strength in the microcosms compared to in situ soil conditions (Barrow and Shaw 1979), are required. Our results are in line with previous studies which show that wetting of soils alter redox conditions and result in mobilization of Fe(II) (Ponnamperuma 1972; Knorr and Blodau 2009; De-Campos et al. 2012; Knorr 2013), and that the prevalence of reducing conditions in the catchment control seasonal variability in $\mathrm{Fe}$ concentrations in Swedish rivers (Ekstrom et al. 2016). 
Fe mobilization from soil to water-the role of $\mathrm{S}$

Contrary to our hypothesis, we found that Fe mobilization was higher in treatments with high $\mathrm{SO}_{4}{ }^{2-}$ concentrations. The positive effect of $\mathrm{HS}$ on $\mathrm{Fe}$ concentrations may have been caused by the lower pH, enhancing Fe dissolution, as well as Fe solubility (Lindsay 1979). Also Mn concentrations were higher in HS throughout the experiment, further supporting that the lower $\mathrm{pH}$ in the high $\mathrm{SO}_{4}{ }^{2-}$ treatments increased solubility and favored reducing activities in anoxic treatments.

There was no loss of $\mathrm{SO}_{4}{ }^{2-}$, as an indication of sulfide production, over the course of the experiment, but rather an increase, which was probably the result of mineralization of organic material. It is unlikely that $\mathrm{SO}_{4}{ }^{2-}$ reduction occured in the anoxic treatments since redox never reached below $200 \mathrm{mV}$ in our microcosms, while $\mathrm{SO}_{4}{ }^{2-}$ reduction typically occurs below $100 \mathrm{mV}$ at pH 3-4 (Takeno 2005). The low pH in our experiment, which is typical for organic horizons of boreal soils, may have disfavored $\mathrm{SO}_{4}{ }^{2-}$ reduction since $\mathrm{SO}_{4}{ }^{2-}$ reducing bacteria are sensitive to low pH (Simek et al. 2014), while Fe(III) reducing bacteria cope well at low pH (Blodau 2006).

High $\mathrm{S}$ deposition has been suggested to have a negative effect on surface water Fe concentrations by reducing DOC mobility (Neal et al. 2008). Organic complexes enhance the solubility of $\mathrm{Fe}$, and may for instance explain the presence of $\mathrm{Fe}(\mathrm{II})$ even in oxic pH-neutral waters (Karlsson and Persson 2012; Daugherty et al. 2017). Affinity of DOC for Fe is reduced at lower $\mathrm{pH}$, due to increased protonation of functional groups of the organic matter (Fang et al. 2015; Neubauer et al. 2013a, b), but Fe can form stable soluble complexes with DOC also in the acidic pH range (3-4) (da Silva et al. 1998). In this study, DOC concentrations were indeed reduced in response to HS, while Fe showed the opposite response. This, and that DOC was available in excess in relation to $\mathrm{Fe}$ in all treatments and throughout the experiment, suggest that an indirect effect of HS on Fe via DOC was not a major factor controlling $\mathrm{Fe}$ mobilization.

Fungi-induced mobilization of Fe and DOC

A marked increase in $\mathrm{Fe}$ concentration in the oxic treatments coincided with detection of fungi dominated by the species Jaapia ochroleuca (Bres.) Nannf.
\& J. Erikss. J. ochroleuca is a rare, but geographically widespread lignicolous species (Eriksson and Ryvarden 1976), that has been frequently reported on sodden and well-decayed wood of both conifers and hardwoods in Sweden and elsewhere (Nannfeldt and Eriksson 1953; Telleria et al. 2015). Although not studied, the increase in $\mathrm{Fe}$ may have been due to solubilization of $\mathrm{Fe}$ and associated nutrients for uptake, organic matter decomposition providing labile organic acids for $\mathrm{Fe}$ reduction, or due to a Fentonmediated active system during growth of J. ochroleuca (see supplementary material for more information). Fungi employ mechanisms for the solubilization and uptake of $\mathrm{Fe}$ found in organic substrates or minerals, including secretion of siderophores with strong affinity to $\mathrm{Fe}$ (III) (Landeweert et al. 2001; Kosman 2013; Sørensen et al. 2014) and small metal solubilizing organic acids (Clarholm et al. 2015). Furthermore, generation of $\mathrm{Fe}(\mathrm{II})$ for non-enzymatic decomposition of plant cell walls is known to exist in brown-rot fungi (Zhu et al. 2016), and some of those mechanisms may be active in certain ectomycorrhizal fungi as well (Shah et al. 2015). Secretion of reducing agents of $\mathrm{Fe}$ (III) (Arantes et al. 2009) facilitate the generation of Fenton reactions, given that a source of hydrogen peroxide exists. As Fenton reactions are most effective at $\mathrm{pH}<4$ (Zhu et al. 2016), the steep increase in total $\mathrm{Fe}$ may have been caused by Fenton reactions induced by the fungus. Although some Fe may have been mobilized by reductive dissolution in the suboxic environment, caused by fungal oxygen consumption, this cannot be the sole explanation considering that $\mathrm{Fe}$ concentrations in the oxic treatments exceeded those in anoxic treatments. Regardless of the specific mechanism causing the $\mathrm{Fe}$ mobilization, the results demonstrate that the action of fungi can have a significant impact on the release of $\mathrm{Fe}$, and subsequently to the amount of Fe released into freshwater systems.

Transition from anoxic to oxic water in the landscape

DOC could play an important role for Fe stability in the riparian zone where $\mathrm{Fe}$ is otherwise sensitive to hydrolysis and precipitation at the oxic-anoxic interface. In our re-oxidation experiment, $\mathrm{Fe}$ from the anoxic treatments was stable against precipitation when exposed to oxic conditions and remained in 
solution. Either the low $\mathrm{pH}-$ and/or the high availability of DOC - in the boreal soil used in this study maintained $\mathrm{Fe}$ in solution even during well-oxygenated conditions. Hence, our results suggest that $\mathrm{Fe}$ would be mobilized at the conditions of the experimental treatments, and that the mobilized Fe may sustain the transition from boreal soils to surface waters.

Re-introduction of air in another soil incubation experiment resulted in $\mathrm{Fe}$ oxide precipitation within 2 days (Schuth et al. 2015). However, pH was higher $(>5)$ and organic carbon concentrations lower (Schuth et al. 2015) than in the current experiment. $\mathrm{Fe}(\mathrm{II})$ oxidation rates are highly sensitive to $\mathrm{pH}$, with $\mathrm{Fe}$ (II) dominating around $\mathrm{pH} 4$, and the presence of complexing agents such as OM has been shown to retard oxidation rates (Theis and Singer 1974; Sung and Morgan 1980; Morgan and Lahav 2007; Jones et al. 2014). Fe has been shown to be mainly associated to $\mathrm{OM}$ at native $\mathrm{pH}(\sim 4)$ in podzol extracts, and to precipitate as $\mathrm{Fe}$ (oxy)hydroxides as $\mathrm{pH}$ increases (Neubauer et al. 2013a, b). Furthermore, previous studies have shown that $\mathrm{Fe}$ is enriched in riparian soil waters-mainly as organic Fe complexes (Sundman et al. 2014) — and that Fe and OM to a large extent are exported from this zone to adjacent stream water (Lidman et al. 2017).

Importantly, we studied mobilization of $\mathrm{Fe}$ and DOC from the organic soil horizon only, potentially representative of superficial runoff or waterlogging of boreal soils or riparian zones. It is apparent that biogeochemical processes in flooded soils differ depending on land-use (De-Campos et al. 2012), as well as between soil horizons. However, the organic soil layer has been identified as a significant source of Fe compared to deeper soil horizons (Giesler et al. 2000; Lidman et al. 2017). Furthermore, increased precipitation, as has been predicted in climate change scenarios for northern latitudes, has been suggested to lead to dominant flow through superficial soil horizons and an increased leaching of organic compounds (Hagedorn et al. 2000; Hongve et al. 2004; Haaland et al. 2010), and reasonably of DOC associated Fe. Moreover, soil slurries may not be entirely representative of processes in intact soils, where microheterogeneity with differences redox conditions, and active vegetation are likely to have an influence (Knorr and Blodau 2009). Somewhat reassuringly, $\mathrm{Fe}$ and DOC concentrations in the oxic treatments at the beginning of the experiment were in the same range as in a field experiment conducted at the same site and with the same $\mathrm{SO}_{4}{ }^{2-}$ treatments (Mean (SD): $\mathrm{Fe}_{\mathrm{LS}}$ $=4.9$ (4.3) $\mu \mathrm{mol} \mathrm{L}{ }^{-1}, \mathrm{Fe}_{\mathrm{HS}}=4.1$ (3.7) $\mu \mathrm{mol} \mathrm{L}{ }^{-1}$, $\mathrm{DOC}_{\mathrm{LS}}=5.8$ (3.5) $\mathrm{mmol} \mathrm{L}^{-1}, \mathrm{DOC}_{\mathrm{HS}}=3.9$ (2.9) mmol L ${ }^{-1}$, pers. communication) (Ekstrom et al. 2011). Hence, while we acknowledge the inherent limitations of soil slurries, we believe these experiments provide important information of Fe mobilization processes in boreal soils.

\section{Conclusions}

Since Fe release from the soil was higher in the high $\mathrm{SO}_{4}{ }^{2-}$ treatment, results from this study does not support that reduced atmospheric $\mathrm{S}$ deposition is a driver behind increasing Fe concentrations in surface waters. On the contrary, the lower $\mathrm{pH}$ as a result of HS likely promoted Fe solubility and $\mathrm{Fe}(\mathrm{III})$ reduction, and hence mobilized more soluble $\mathrm{Fe}$ species. Although the high availability of DOC for complexation most likely maintained $\mathrm{Fe}$ in solution, the fact that DOC was negatively affected by higher $\mathrm{SO}_{4}{ }^{2-}$ concentrations suggests that redox and $\mathrm{pH}$ along with mobilizing processes induced by the fungus $J$. ochroleuca were more important in controlling $\mathrm{Fe}$ release from soil to the aqueous phase. Hence, although Fe and DOC have been shown to be tightly connected in soils and water, the factors that control their mobilization and concentration in the aqueous phase are partly different. Finally, while Fe is often assumed to be lost in the transition from anoxic to oxic water in the riparian zone, our study show that Fe may stay in solution as anoxic soil horizons connect with oxidized surface water.

Acknowledgements Open access funding provided by Lund University. This work was supported by the Swedish Research Council (Grant No. 2015-05450) and Formas (942-2015-14) to E.S.K. This work was part of the research program Molecular Interactions Controlling soil Carbon Sequestration (MICCS) funded by the Knut and Alice Wallenberg Foundation, and Lund University Centre for studies of Carbon Cycle and Climate Interactions (LUCCI). We thank Sofia Mebrahtu Wisén at the Stable Isotope Service Lab, Department of Biology, Lund University, for assistance with chemical analyses.

Open Access This article is distributed under the terms of the Creative Commons Attribution 4.0 International License (http:// creativecommons.org/licenses/by/4.0/), which permits unrestricted use, distribution, and reproduction in any medium, 
provided you give appropriate credit to the original author(s) and the source, provide a link to the Creative Commons license, and indicate if changes were made.

\section{References}

Arantes V, Qian YH, Milagres AMF, Jellison J, Goodell B (2009) Effect of $\mathrm{pH}$ and oxalic acid on the reduction of $\mathrm{Fe}^{3+}$ by a biomimetic chelator and on $\mathrm{Fe}^{3+}$ desorption/ adsorption onto wood: implications for brown-rot decay. Int Biodeterior Biodegrad 63:478-483

Atta SK, Mohammed SA, VanCleemput O, Zayed A (1996) Transformations of iron and manganese under controlled $\mathrm{E}(\mathrm{h}), \mathrm{E}(\mathrm{h})-\mathrm{pH}$ conditions and addition of organic matter. Soil Technol 9:223-237

Bakker ES, Van Donk E, Immers AK (2016) Lake restoration by in-lake iron addition: a synopsis of iron impact on aquatic organisms and shallow lake ecosystems. Aquat Ecol 50:121-135

Barrow NJ, Shaw TC (1979) Effects of ionic-strength and nature of the cation on desorption of phosphate from soil. J Soil Sci 30:53-65

Bastviken D, Persson L, Odham G, Tranvik L (2004) Degradation of dissolved organic matter in oxic and anoxic lake water. Limnol Oceanogr 49:109-116

Berggren D, Bergkvist B, Johansson M-B, Melkerud P-A, Nilsson A, Olsson M, Langvall O, Majdi H, Weslien P (2004) A description of LUSTRA's common field sites. Swedish Univ. of Agricultural Sciences, Uppsala

Bergkvist B (1986) Leaching of metals from a spruce forest soil as influenced by experimental acidification. Water Air Soil Pollut 31:901-916

Bergkvist B (1987) Soil solution chemistry and metal budgets of spruce forest ecosystems in S-Sweden. Water Air Soil Pollut 33:131-154

Björnerås $\mathrm{C}$, Weyhenmeyer GA, Evans $\mathrm{CD}$, Gessner MO, Grossart HP, Kangur K, Kokorite I, Kortelainen P, Laudon H, Lehtoranta J, Lottig N, Monteith DT, Nõges P, Nõges T, Oulehle F, Riise G, Rusak JA, Räike A, Sire J, Sterling S, Kritzberg ES (2017) Widespread increases in iron concentration in European and North American freshwaters. Global Biogeochem Cycles 31:1488-1500

Blodau C (2006) A review of acidity generation and consumption in acidic coal mine lakes and their watersheds. Sci Total Environ 369:307-332

Bottrell SH, Mortimer RJG, Spence M, Krom MD, Clark JM, Chapman PJ (2007) Insights into redox cycling of sulfur and iron in peatlands using high-resolution diffusive equilibrium thin film (DET) gel probe sampling. Chem Geol 244:409-420

Chen J, Blume HP, Beyer L (2000) Weathering of rocks induced by lichen colonization-a review. CATENA 39:121-146

Clarholm M, Skyllberg U (2013) Translocation of metals by trees and fungi regulates $\mathrm{pH}$, soil organic matter turnover and nitrogen availability in acidic forest soils. Soil Biol Biochem 63:142-153

Clarholm M, Skyllberg U, Rosling A (2015) Organic acid induced release of nutrients from metal-stabilized soil organic matter-the unbutton model. Soil Biol Biochem 84:168-176

da Silva JCG, Machado A, Oliveira CJS (1998) Effect of pH on complexation of Fe(III) with fulvic acids. Environ Toxicol Chem 17:1268-1273

Daugherty EE, Gilbert B, Nico PS, Borch T (2017) Complexation and redox buffering of iron(II) by dissolved organic matter. Environ Sci Technol 51:11096-11104

De-Campos AB, Huang CH, Johnston CT (2012) Biogeochemistry of terrestrial soils as influenced by short-term flooding. Biogeochemistry 111:239-252

Drever JI (1994) The effect of land plants on weathering rates of silicate minerals. Geochim Cosmochim Acta 58:2325-2332

Ekstrom SM, Kritzberg ES, Kleja DB, Larsson N, Nilsson PA, Graneli W, Bergkvist B (2011) Effect of acid deposition on quantity and quality of dissolved organic matter in soilwater. Environ Sci Technol 45:4733-4739

Ekstrom SM, Regnell O, Reader HE, Nilsson PA, Lofgren S, Kritzberg ES (2016) Increasing concentrations of iron in surface waters as a consequence of reducing conditions in the catchment area. J Geophys Res-Biogeosci 121:479-493

Eriksson J, Ryvarden L (1976) The Corticiaceae of North Europe 4,547-886. Fungiflora, Oslo

Fang K, Yuan D, Zhang L, Feng L, Chen Y, Wang Y (2015) Effect of environmental factors on the complexation of iron and humic acid. J Environ Sci 27:188-196

Fiedler S, Kalbitz K (2003) Concentrations and properties of dissolved organic matter in forest soils as affected by the redox regime. Soil Sci 168:793-801

Froberg M, Kleja DB, Bergkvist B, Tipping E, Mulder J (2005) Dissolved organic carbon leaching from a coniferous forest floor-a field manipulation experiment. Biogeochemistry 75:271-287

Garmo OA, Skjelkvale BL, de Wit HA, Colombo L, Curtis C, Folster J, Hoffmann A, Hruska J, Hogasen T, Jeffries DS, Keller WB, Kram P, Majer V, Monteith DT, Paterson AM, Rogora M, Rzychon D, Steingruber S, Stoddard JL, Vuorenmaa J, Worsztynowicz A (2014) Trends in surface water chemistry in acidified areas in Europe and North America from. Water Air Soil Pollut 225:1880

Giesler R, Ilvesniemi H, Nyberg L, van Hees P, Starr M, Bishop K, Kareinen T, Lundstrom US (2000) Distribution and mobilization of $\mathrm{Al}, \mathrm{Fe}$ and $\mathrm{Si}$ in three podzolic soil profiles in relation to the humus layer. Geoderma 94:249-263

Grybos M, Davranche M, Gruau G, Petitjean P, Pedrot M (2009) Increasing $\mathrm{pH}$ drives organic matter solubilization from wetland soils under reducing conditions. Geoderma 154:13-19

Haaland S, Hongve D, Laudon H, Riise G, Vogt RD (2010) Quantifying the drivers of the increasing colored organic matter in boreal surface waters. Environ Sci Technol 44:2975-2980

Hagedorn F, Kaiser K, Feyen H, Schleppi P (2000) Effects of redox conditions and flow processes on the mobility of dissolved organic carbon and nitrogen in a forest soil. J Environ Qual 29:288-297

Hongve D, Riise G, Kristiansen JF (2004) Increased colour and organic acid concentrations in Norwegian forest lakes and 
drinking water-a result of increased precipitation? Aquat Sci 66:231-238

Humborg C, Smedberg E, Blomqvist S, Morth CM, Brink J, Rahm L, Danielsson A, Sahlberg J (2004) Nutrient variations in boreal and subarctic Swedish rivers: landscape control of land-sea fluxes. Limnol Oceanogr 49:1871-1883

Jansen B, Nierop KGJ, Verstraten JM (2004) Mobilization of dissolved organic matter, aluminium and iron in podzol eluvial horizons as affected by formation of metal-organic complexes and interactions with solid soil material. Eur J Soil Sci 55:287-297

Jones AM, Griffin PJ, Collins RN, Waite TD (2014) Ferrous iron oxidation under acidic conditions-the effect of ferric oxide surfaces. Geochim Cosmochim Acta 145:1-12

Kaiser K, Guggenberger G (2000) The role of DOM sorption to mineral surfaces in the preservation of organic matter in soils. Org Geochem 31:711-725

Karlsson T, Persson P (2012) Complexes with aquatic organic matter suppress hydrolysis and precipitation of $\mathrm{Fe}(\mathrm{III})$. Chem Geol 322:19-27

Kleja DB, Svensson M, Majdi H, Jansson PE, Langvall O, Bergkvist B, Johansson MB, Weslien P, Truusb L, Lindroth A, Agren GI (2008) Pools and fluxes of carbon in three Norway spruce ecosystems along a climatic gradient in Sweden. Biogeochemistry 89:7-25

Knorr KH (2013) DOC-dynamics in a small headwater catchment as driven by redox fluctuations and hydrological flow paths - are DOC exports mediated by iron reduction/oxidation cycles? Biogeosciences 10:891-904

Knorr KH, Blodau C (2009) Impact of experimental drought and rewetting on redox transformations and methanogenesis in mesocosms of a northern fen soil. Soil Biol Biochem 41:1187-1198

Knorr K-H, Lischeid G, Blodau C (2009) Dynamics of redox processes in a minerotrophic fen exposed to a water table manipulation. Geoderma 153:379-392

Kosman DJ (2013) Iron metabolism in aerobes: managing ferric iron hydrolysis and ferrous iron autoxidation. Coord Chem Rev 257:210-217

Kritzberg ES, Ekstrom SM (2012) Increasing iron concentrations in surface waters - a factor behind brownification? Biogeosciences 9:1465-1478

Kuesel K, Roth U, Drake HL (2001) Microbial reduction of $\mathrm{Fe}(\mathrm{III})$ in the presence of oxygen under low $\mathrm{pH}$ conditions. Abstracts of the General Meeting of the American Society for Microbiology. Environ Microbiol 101:519

Lalonde K, Mucci A, Ouellet A, Gelinas Y (2012) Preservation of organic matter in sediments promoted by iron. Nature 483:198-200

Landeweert R, Hoffland E, Finlay RD, Kuyper TW, van Breemen N (2001) Linking plants to rocks: ectomycorrhizal fungi mobilize nutrients from minerals. Trends Ecol Evol $16: 248-254$

Ledesma JLJ, Grabs T, Futter MN, Bishop KH, Laudon H, Kohler SJ (2013) Riparian zone control on base cation concentration in boreal streams. Biogeosciences 10:3849-3868

Lidman F, Boily A, Laudon H, Kohler SJ (2017) From soil water to surface water-how the riparian zone controls element transport from a boreal forest to a stream. Biogeosciences 14:3001-3014
Lindsay WL (1979) Chemical equilibria in soils. Wiley, Hoboken

Lovley DR (1991) Dissimilatory Fe(III) and Mn(IV) reduction. Microbiol Rev 55:259-287

Lundstrom US, van Breemen N, Bain D (2000) The podzolization process. A review. Geoderma 94:91-107

Monteith DT, Stoddard JL, Evans CD, de Wit HA, Forsius M, Hogasen T, Wilander A, Skjelkvale BL, Jeffries DS, Vuorenmaa J, Keller B, Kopacek J, Vesely J (2007) Dissolved organic carbon trends resulting from changes in atmospheric deposition chemistry. Nature 450:U537U539

Moore TR (1988) Dissolved iron and organic-matter in northern peatlands. Soil Sci 145:70-76

Morgan B, Lahav O (2007) The effect of pH on the kinetics of spontaneous $\mathrm{Fe}$ (II) oxidation by $\mathrm{O}-2$ in aqueous solutionbasic principles and a simple heuristic description. Chemosphere 68:2080-2084

Musolff A, Selle B, Bttner O, Opitz M, Tittel J (2017) Unexpected release of phosphate and organic carbon to streams linked to declining nitrogen depositions. Glob Change Biol 23:1891-1901

Nannfeldt J, Eriksson J (1953) On the hymenomycetous genus Jaapia Bres and its taxonomical position. Svensk Bot Tidskr 47:177-189

Neal C, Lofts S, Evans CD, Reynolds B, Tipping E, Neal M (2008) Increasing iron concentrations in UK upland waters. Aquat Geochem 14:263-288

Neubauer E, Kohler SJ, von der Kammer F, Laudon H, Hofmann $\mathrm{T}$ (2013a) Effect of $\mathrm{pH}$ and Stream Order on Iron and Arsenic Speciation in Boreal Catchments. Environ Sci Technol 47:7120-7128

Neubauer E, Schenkeveld WDC, Plathe KL, Rentenberger C, von der Kammer F, Kraemer SM, Hofmann T (2013b) The influence of $\mathrm{pH}$ on iron speciation in podzol extracts: iron complexes with natural organic matter, and iron mineral nanoparticles. Sci Total Environ 461:108-116

Nurnberg GK, Dillon PJ (1993) Iron budgets in temperate lakes. Can J Fish Aquat Sci 50:1728-1737

Påhlsson A-MB, Bergkvist B (1995) Acid deposition and soil acidification at a southwest facing edge of Norway spruce and European beech in south Sweden. Ecol Bull (Stockholm) 44:43-53

Pan WN, Kan J, Inamdar S, Chen CM, Sparks D (2016) Dissimilatory microbial iron reduction release DOC (dissolved organic carbon) from carbon-ferrihydrite association. Soil Biol Biochem 103:232-240

Ponnamperuma FN (1972) The chemistry of submerged soils. Adv Agron 24:29-96

Sanden P, Grimvall A, Lohm U (1987) Acidification trends in Sweden. Water Air Soil Pollut 36:259-270

Sarkkola S, Nieminen M, Koivusalo H, Lauren A, Kortelainen P, Mattsson T, Palviainen M, Piirainen S, Starr M, Finer L (2013) Iron concentrations are increasing in surface waters from forested headwater catchments in eastern Finland. Sci Total Environ 463:683-689

Schopp W, Posch M, Mylona S, Johansson M (2003) Long-term development of acid deposition (1880-2030) in sensitive freshwater regions in Europe. Hydrol Earth Syst Sci 7:436-446 
Schuth S, Hurrass J, Muenker C, Mansfeldt T (2015) Redoxdependent fractionation of iron isotopes in suspensions of a groundwater-influenced soil. Chem Geol 392:74-86

Shah F, Schwenk D, Nicolas C, Persson P, Hoffmeister D, Tunlid A (2015) Involutin is an $\mathrm{Fe}^{3+}$ reductant secreted by the ectomycorrhizal fungus Paxillus involutus during fenton-based decomposition of organic matter. Appl Environ Microbiol 81:8427-8433

Simek M, Virtanen S, Simojoki A, Chronakova A, Elhottova D, Krigtufek V, Yli-Halla M (2014) The microbial communities and potential greenhouse gas production in boreal acid sulphate, non-acid sulphate, and reedy sulphidic soils. Sci Total Environ 466:663-672

Skoog AC, Arias-Esquivel VA (2009) The effect of induced anoxia and reoxygenation on benthic fluxes of organic carbon, phosphate, iron, and manganese. Sci Total Environ 407:6085-6092

Sørensen JL, Knudsen M, Hansen FT, Olesen C, Fuertes PR, Lee TV, Sondergaard TE, Pedersen CNS, Brodersen DE, Giese H (2014) Fungal NRPS-dependent siderophores: from function to prediction. In: Martín J-F, Garcia-Estrada $\mathrm{C}$, Zeilinger S (eds) Biosynthesis and molecular genetics of fungal secondary metabolites. Springer, New York, pp 317-339

Stumm W, Morgan JJ (1996) Aquatic chemistry: chemical equilibria and rates in natural waters, 3 rd edn. Wiley, New York

Sundman A, Karlsson T, Laudon H, Persson P (2014) XAS study of iron speciation in soils and waters from a boreal catchment. Chem Geol 364:93-102

Sung W, Morgan JJ (1980) Kinetics and product of ferrous iron oxygenation in aqueous systems. Environ Sci Technol 14:561-568

SS-28311 (2017) Soil analysis-determination of trace elements in soil by extraction with nitric acid. Swedish Standards Institute, Stockholm
Takeno N (2005) Atlas of Eh-pH diagrams. Geological survey of Japan open file report 419:102

Telleria MT, Duenas M, Melo I, Salcedo I, Martin MP (2015) Spelling out Jaapia species. Mycol Prog 14:57

Theis TL, Singer PC (1974) Complexation of iron(II) by organic-matter and its effect on iron(II) oxygenation. Environ Sci Technol 8:569-573

Viollier E, Inglett PW, Hunter K, Roychoudhury AN, Van Cappellen P (2000) The ferrozine method revisited: Fe(II)/ $\mathrm{Fe}(\mathrm{III})$ determination in natural waters. Appl Geochem 15:785-790

von Wachenfeldt E, Sobek S, Bastviken D, Tranvik LJ (2008) Linking allochthonous dissolved organic matter and boreal lake sediment carbon sequestration: the role of light-mediated flocculation. Limnol Oceanogr 53:2416-2426

Weyhenmeyer GA, Prairie YT, Tranvik LJ (2014) Browning of boreal freshwaters coupled to carbon-iron interactions along the aquatic continuum. PLoS ONE. https://doi.org/ 10.1371/journal.pone.0088104

Xiao Y-H, Sara-Aho T, Hartikainen H, Vähätalo AV (2013) Contribution of ferric iron to light absorption by chromophoric dissolved organic matter. Limnol Oceanogr 58:653-662

Zhu Y, Zhuang LP, Goodell B, Cao JZ, Mahaney J (2016) Iron sequestration in brown-rot fungi by oxalate and the production of reactive oxygen species (ROS). Int Biodeterior Biodegrad 109:185-190

Publisher's Note Springer Nature remains neutral with regard to jurisdictional claims in published maps and institutional affiliations. 